УДК 378:811.11

DOI https://doi.org/10.52726/as.pedagogy/2021.3.1.19

\author{
А. Л. ФРУМКІНА \\ кандидат філологічних наук, доцент, \\ доиент кафедри іноземних мов № 2, \\ Наиіональний університет «Одеська юридична академія», \\ м. Одеса, Україна \\ Електронна пошта: frumkina@опиа.edu.ua \\ http://orcid.org/0000-0003-2635-685X
}

\title{
ЛІНГВОДИДАКТИЧНІ ПРИНЦИПИ ОРГАНІЗАЦІЇ ПІДГОТОВКИ МАЙБУТНІХ УЧИТЕЛІВ ПОЧАТКОВИХ КЛАСІВ ДО ІНТЕГРОВАНОЇ ПРОФЕСІЙНОЇ ДІЯЛЬНОСТІ
}

У статті представлена проблема визначення принципів підготовки майбутніх учителів початкових класів до їх інтегрованої професійної діяльності іноземною мовою. Наведено та порівняно принципоутворювальні системи підготовки майбутніх учителів різних профілів. Встановлено лінгводидактичні принципи організації підготовки майбутніх учителів початкових класів до інтегрованої професійної діяльності. Цими принципами є: 1) принцип процесуальної інтеграції викладання двох різнотипних предметів у єдиному процесі навчання; 2) принцип мотивації професійної діяльності як в аспекті навчання образотворчого мистецтва молодших школярів, так і в аспекті вивчення іноземної мови як засобу викладання основного предмету; 3) принцип самореалізації вчителя в його високорівневій художній майстерності і безперешкодному володінні іноземною мовою в загальнонавчальних і соціально-комунікативній формах; 4) принцип високорівневої методичної компетентності педагога, заснованої на сукупності художньо-образотворчої, лінгвокомунікатівної і методичної компетенцій; 5) принцип рефлексивнозумовленої самоосвіти, який проявляється в рефлексивній потребі пізнання нової інформації, у висуванні цілей самовдосконалення і способів їх досягнення; вивченні професійної літератури, в тому числі й іншомовної; спробі реалізувати свої професійні можливості в нових видах живопису й іншомовному коментуванні своїх дій; поглибленні своїх теоретичних знань через різноманітні дослідні роботи; 6) принцип безпрервності освіти, який має прояв в набутті базових знань і умінь за дисциплінами, що вивчаються, та їх вдосконаленні протягом усього свідомого життя; 7) принцип готовності педагога до його професійної діяльності, який проявляється в здатності передачі учням своїх знань та умінь в галузі предмета, що викладається.

Ключові слова: лінгводидактичні принципи, професійна діяльність, інтегроване навчання, учителі початкової школи.

Постановка проблеми. Професійна діяльність учителя початкових класів посідає особливе місце в низці інших педагогічних професій, що пояснюється насамперед унікальністю цієї діяльності, іiі роллю в розвитку подальшого життя дитини. Крім того, сьогодні надзвичайно актуальна підготовка вчителів, які мають не тільки високий компетентнісний рівень у своїй професії, а й вільно володіють іноземною мовою як засобом вирішення педагогічних завдань. Саме тому на перший план у системі підготовки майбутніх учителів початкової школи висуваються вимоги, пов'язані із лінгвістичною і дидактико-методичною підготовкою студентів до майбутньої професійної діяльності.

У вітчизняній та зарубіжній психології і педагогіці вже визначено ряд методологічних принципів, які можна покласти в основу модернізації професійної підготовки фахівців. Однак ці принципи не завжди враховують функції та особливості педагогічної діяльності вчителя в контексті специфіки змісту навчального предмета.

Аналіз попередніх досліджень. Розробкою концептуальних основ підготовки педагогів до викладання різнотипних дисциплін займалися багато дослідників. Вони обгрунтовували свої концепції підготовки крізь систему загально дидактичних та специфічних для конкретних предметів принципів. Такі принципоутворювальні системи підготовки забезпечували майбутнім учителям різних профілів науковість, всебічність, логічність, послідовність, непрерівність в отриманні та вдосконаленні їх профільних знань.

Так, О. Шквир для наукової організації підготовки майбутніх учителів початкових класів 
до їх професійної діяльності пропонує такі загально дидактичні принципи: «неперервності, наступності, професійної спрямованості, єдності наукової та навчальної діяльності, проблемності, професійної мобільності, урахування вікових та індивідуальних особливостей студентів» [Шквир 2018].

Своєю чергою I. Андрощук обгрунтовує свою систему підготовки майбутніх вчителів трудового виховання такими загально дидактичними принципами, як: науковості, наступності, гуманізації, інтегрованості, безперервності зв'язку теорії з практикою, наочності; та такими специфічними принципами щодо предмета викладання: моделювання, суб'єктсуб'єктної взаємодії, співробітництва, самоорганізації, діалогізації, інтердисциплінарності, створення розвивального освітнього середовища [Андрощук 2018].

М. Білянська в своїй роботі 3 підготовки майбутніх учителів біології також оперує в роботі загально дидактичними та специффічними принципами. До перших вона відносить принципи: науковості, доступності, системності і послідовності, безперервності, практичного спрямування, свідомості і активності, демократичності, гуманізації і гуманітаризації, інтегративності, варіативності. До других вчена відносить такі принципи, як: гнучкості, прогностичності, сучасності, взаємодоповнюваності еколого-педагогічної та професійної діяльності, а також краєзнавчий принцип [Білянська 2018 : 240].

Т. Демидова згрупувала принципи побудови моделі професійної підготовки учителів молодших класів у три блоки: загально дидактичні: міжпредметних зв'язків, доступності, науковості, ситуативності навчання, продуктивності навчання; системні: інтегративності, мобільності, спадкоємності, технологічності; спещіальні: професійно-цільового підходу з урахуванням специфіки майбутньої діяльності; інтеграції теорії та практики; педагогічного співробітниųтва на основі гуманізації та демократизації відносин педагога і учнів; активності особистості в оволодінні професійною готовністю до формування загально навчальних умінь у молодших школярів; проблемності змісту цієї підготовки майбутнього учителя; самовдосконалення особистості [Демидова 2006].
В. Іщук, розглядаючи професійну підготовку майбутніх учителів фізичної культури на основі контекстного і проєктного навчання, виділяє: загально педагогічні принциии: свідомості та активності, систематичності та послідовності, врахування індивідуальних й вікових особливостей; принципи фізичного виховання: оздоровчої спрямованості; зв'язку фізичного виховання з іншими видами діяльності та зайнятості людей; принципи проєктування: технологічності, системного моніторингу; принциии контекстного навчання: проблемності, спільної колективної діяльності, рефлексивності [Іщук $2014: 765$ ].

О. Чиранова, вивчаючи підготовку майбутнього учителя математики до реалізації естетичного потенціалу початкового курсу математики, виділяе такі принципи: культуродоцільності виховання підлітків; універсальності процесу навчання; творчого розвитку особистості; самостійності та безперервності в надбанні знань; емоційної насиченості навчально-педагогічних дій, як з боку вчителя, так і з боку учнів; проблемності в навчанні дітей $з$ різними математичними здібностями [Чиранова 2006].

Не применшуючи переваги жодної з вищенаведених концепцій підготовки майбутніх учителів до їх викладацької діяльності, відзначимо, що жодна 3 них не може бути прийнята нами повною мірою. Це зумовлюється тим, що ці роботи припускають навчання майбутніх педагогів однієї профільної дисципліни та методики ії викладання учням певних вікових груп. У психологічному аспекті це виражається в достатності сприйняття, осмислення, запам'ятовування та застосування досліджуваних педагогічних і профільних дисциплін на їхній рідній мові.

Мета статті - визначення принципів підготовки майбутніх учителів початкових класів до їх інтегрованої професійної діяльності іноземною мовою.

Виклад основного матеріалу. У нашій системі підготовки майбутніх учителів є дві різнопрофільні та різнотипні за структурою й змістом дисципліни: образотворче мистецтво та іноземна мова. Причому іноземна мова не як окремий навчальний предмет, а як засіб викладання основного освітнього предмета. У психологічному аспекті це вимагає одночасного 
засвоєння основної дисципліни, методики іiї викладання та формування іншомовного динамічного стереотипу для забезпечення вільного та безперешкодного сприйняття, осмислення, запам'ятовування і застосування предметних знань в їх іншомовному супроводі. Саме тому нашим головним і основним принципом підготовки майбутніх вчителів початкових класів до їх професійної діяльності на іноземній мові є принцип процесуальної інтеграції взаємопов'язаного викладання двох різнотипних предметів [Мартинова 2016].

В більшості випадків під інтегрованим навчанням розуміється «объединение нескольких учебных предметов в одни, в котором научные понятия связаны общим смыслом и методами преподавания» [Зверев 1974: 10-16]. Специфічною характеристикою інтеграції $\epsilon$ «образование единой предметной общности, которая выражается смысловой взаимосвязью частей предметного содержания и составляет единую разноаспектную информацию» [Тюников $1988: 7-12]$.

Наведені характеристики інтеграції типові для об'єднання в єдине ціле хоча і різних предметів, але утворюючих спільність за певними смисловим категоріям [Фрумкіна 2020 : 504]. Наприклад, предмет «Наш край» включає такі його характеристики, які співвідносяться з різними галузями знань, а саме: історією, географією, екологією, ботанікою, зоологією, літературою. Така інтеграція називається предметною. У нашому разі підготовка викладачів здійснюється на основі інтеграції не предметів, оскільки вони різнотипні, а процесів їх викладання. Така інтегрована форма підготовки майбутніх учителів різнопрофільних дисциплін, одна 3 яких іноземна мова, передбачає високий рівень їх мотивації до позначеної викладацької роботи.

Будь-яка професійна діяльність, особливо педагогічна, навряд чи буде успішною без іiі високої мотивації, причому не стільки зовнішньої: престижна професія, високооплачувана робота, комфортні умови життєдіяльності, скільки внутрішньої: високий інтерес до своєї роботи, ментальні потреби в рішенні професійних завдань і наявних здібностей до творення в конкретній галузі знань.

У зв'язку 3 цим одним 3 принципів підготовки майбутніх учителів до професійної діяльності вважаємо мотиваційний, під яким розуміється «прагнення до поліпшення результатів у власній професійній діяльності, стійке бажання щодо їх удосконалення та самостійний пошук шляхів щодо здійснення мети самоосвіти» [Мартинова 2016].

В аспекті предметно-образотворчої діяльності - це бажання майбутніх педагогів передати школярам почуття прекрасного, любові до природи, до навколишньої дійсності, формування у них естетичного смаку, а також умінь передачі всього цього через художню графіку i самостійно створений сюжетний малюнок.

В аспекті іншомовно-мовленнєвої діяльності - це не тільки розуміння необхідності високого рівня володіння іноземною мовою на сучасному етапі розвитку нашого суспільства, але і бажання залучення учнів до культури і мистецтва інших народів, розуміння їх традицій, звичаїв, специфіки мовного спілкування через оволодіння їх рідною мовою.

Успіх підготовки майбутніх учителів до такої інтегрованої форми навчання учнів початкових класів багато в чому залежить від уміння залучити учнів до незвичайної форми навчального процесу, в якому одночасно вивчаються два предмета: образотворче мистецтво та іноземна мова. Одним 3 найбільш дієвих способів залучення учнів до описуваної форми навчання $\epsilon$ висока культура та компетентність самого педагога в даних галузях знань, тому наступним принципом організації підготовки майбутніх учителів початкових класів до інтегрованої професійної діяльності вважаємо принцип самореалізації учителя, під яким, слідом за В. Клочко та Е. Галажінскім, розуміємо «осознанный процесс, требующий от человека волевых усилий, активности и целеустремленности для выражения собственных мыслей, своей обоснованной точки зрения и представления своего варианта решения профессиональных задач» [Клочко 1999].

В аспекті предметно-образотворчої діяльності він проявляється в здатності педагога малювати різноманітні предмети навколишньої дійсності, точно передавати їх виразність підбором та поєднанням кольорів, наявністю власних творів живопису в його різноманітних формах та течіях (реалізмі, кубізмі, імпресіонізмі), а також участю в багатьох художніх виставках. 
В аспекті іншомовно-мовленнєвої діяльності високий рівень самореалізації проявляється у вільному володінні іноземною мовою, здатності читати іншомовну професійну літературу, спілкуватися з носіями мови в цій галузі знань. Перераховані особистісні можливості педагога привертають увагу учнів, викликають у них повагу до вчителя та його авторитету як до художника, так і до педагога, який володіє іноземною мовою.

Однак високий професійний рівень учителя в двох розглянутих видах діяльності не є достатнім для передачі його знань учням. Останнє вимагає педагогічної майстерності викладача, яка проявляється в здатності передачі свого досвіду, як художнього, так і іншомовного, учням, тому вважаємо таким принципом підготовки майбутніх учителів початкових класів до інтегрованої професійної діяльності принцип високорівневої методичної компетентності педагога, під яким ми розуміємо його «готовність до передачі своїх знань і умінь учням в галузі предмета та досягнення у них високих результатів навчання» [Боднар 2016: 104]. Цей принцип реалізується в: 1) здатності розподілити весь навчальний зміст необхідного для засвоєння матеріалу на частини, що поступово ускладняються; 2) активізації уваги учнів до виконання образотворчих дій в їх іншомовному супроводі; 3 ) чіткому, зрозумілому та логічному поясненні кожного руху руки задля досягнення необхідної графічної форми предмета, а також нормативного фонетичного озвучування англійською мовою відповідних предметно-зображальних дій; 4) навчанні учнів користуватися комп'ютерними програмами задля досягнення результатів у малюванні та одночасному володінні відповідною іноземною мовою.

Вищеописані рівні професійної та методичної компетентності учителя будуть стимулювати його до постійної творчої діяльності, як у галузі предмета малювання, так і в галузі предмета іноземна мова, що закладе основи для подальшої самоосвіти. Отже, вважаємо наступнім принципом підготовки майбутніх учителів початкових класів до інтегрованої професійної діяльності принцип самоосвіти. Реалізація цього принципу досягається шляхом: 1) рефлексивної потреби пізнання нової інформації в досліджуваних галузях знань; 2) висування цілей самовдосконалення та способів їх досягнення; 3) самостійного відбору та читання професійної літератури, як рідною, так і іноземною мовами; 4) вивчення видів художньої творчості, що знову виникають та спробою реалізувати свої в них професійні можливості; 5) подання своїх робіт на художні конкурси, як у країні, так і за їі межами; 6) поглиблення своїх теоретичних знань у вигляді подання доповідей з образотворчого мистецтва іноземною мовою на міжнародних конференціях; 7) написання наукових статей та проведення дисертаційних досліджень в обраній галузі знань.

Описаний рівень самоосвіти призводить до безперервності процесу навчання майбутніх педагогів, що відповідає принципу безперервності освіти в процесі підготовки майбутніх учителів образотворчого мистецтва на іноземній мові.

Що стосується безперервності освіти, С. Гончаренко пише: «Неперервна освіта як педагогічна система - це сукупність засобів, способів і форм набуття, поглиблення і розширення загальної освіти, професійної компетентності, культури, виховання, громадської і моральної зрілості. Для кожної людини неперервна освіта виступає процесом формування і задоволення іiі пізнавальних запитів і духовних потреб, розвитку задатків і здібностей в мережі державногромадських навчальних закладів i шляхом самоосвіти» [Гончаренко 2011 : 318-319].

У нашому разі безперервність освіти майбутніх вчителів малювання зі знанням іноземної мови як способу реалізації своєї професійної діяльності починається в отриманні базових знань та умінь в галузі образотворчого мистецтва й процесі іншомовної комунікації за професійним спрямуванням; триває в позанавчальній діяльності вдосконаленням своїх знань та умінь в галузі образотворчого мистецтва шляхом: читання додаткової професійної літератури, спілкування з видатними художниками сучасності, відвідування виставок їхніх творів та наслідування техніки їх образотворчої майстерності; в галузі поглиблення іншомовних знань та умінь шляхом: читання оригінальної художньої літератури, зустрічей із зарубіжними майстрами мистецтв, поданням своїх робіт на різних художніх виставках. Така творча професійна діяльність не має закінчення, вона триває все свідоме життя людини. 
Підсумковим принципом підготовки майбутніх вчителів початкових класів до їх педагогічної діяльності на іноземній мові вважаємо принцип їх готовності до такої роботи. 3 огляду на, що готовність будь-якого педагогапредметника включає взаємодію педагогічних, психологічних, предметних та методичних аспектів його діяльності, викладемо своє бачення їх змісту стосовно майбутнього вчителя вищеозначеного профілю.

1. Ознаки педагогічної готовності майбутнього вчителя: 1) володіння теорією навчально-виховної діяльності видатних педагогів минулих років та сучасників; 2) здатність реалізовувати їх теорії на практиці під час вирішення глобальних й поточних педагогічних завдань; 3) вміння використовувати зміст навчального предмета як засобу виховання особистості; 4) здатність недопущення конфліктних ситуацій у процесі навчання; проте, в разі ïх виникнення, - здатність до справедливого та толерантного їх вирішення.

\section{2. Ознаки психологічної готовності май-} бутнього учителя: 1) знання теоретичних основ розвитку особистості учнів певного віку: ïх мислення, пам'яті та уваги; 2) знання різних способів досягнення сприйняття і осмислення нової інформації та способів іiі застосування задля довготривалого володіння нею; 3) вміння диференціювати види темпераментів дітей задля врахування їх індивідуальних можливостей досягнення результатів навчання.

3. Ознаки предметної готовності майбутнього учителя. У нашому разі розглянемо ознаки готовності вчителя 3 двох предметів: малювання та іноземної мови.

3 предмету образотворче мистеитво: 1) знати: теоретичні основи образотворчого мистецтва; вміти: застосовувати знання теоретичних основ образотворчого мистецтва на практиці; 2) знати: термінологію і засоби художньої виразності, що застосовуються в процесі образотворчої діяльності; вміти: використовувати спеціальну термінологію, прийняту в образотворчій діяльності, і засоби художньої виразності як засіб естетичного виховання і художньої освіти молодших школярів; 3) знати: види, жанри образотворчого та декоративно-прикладного мистецтва, що використовуються в роботі 3 дітьми; вміти: організовувати сприйняття дітьми творів образотворчого та декоративноприкладного мистецтва; 4) знати: різні види техніки живопису і технології роботи 3 основними мальовничими і графічними матеріалами; вміти: навчити дітей видам живопису та роботі 3 основними мальовничими та графічними матеріалами; 5) знати: закони композиції, правила перспективи та побудови малюнка, основи кольорознавства; вміти: створювати композиції в галузі графіки, живопису, скульптури, аналізувати колірний стан натури або композиції, складати хроматичні колірні ряди; 6) знати: особливості розвитку образотворчої творчості у дітей молодшого шкільного віку; вміти: розвивати художньо-творчі здібності дітей; 7) знати: методику підготовки та проведення уроків 3 малювання в початковій школі, в тому числі спрямовані на втілення творчого задуму; вміти: планувати, готувати та проводити уроки з малювання в початковій школі, самостійно обирати методи, форми та засоби навчання для уроків [Типова навчальна програма].

Вчитель з предмету «Іноземна мова» повинен володіти: 1) іншомовним словниковим запасом в обсязі 2500 лексичних одиниць, що включають всю предметну термінологію; 2) здатністю безпомилкового виконання будь-яких завдань у межах рівня В2 відповідно до Загальноєвропейських Рекомендацій з мовної освіти за всіма видами мовленнєвої діяльності; 3) соціокультурною інформацією $з$ життя, побуту, звичаїв, традицій носіїв мови, що вивчається.

4. Ознаки методичної готовності майбутнього вчителя: 1) здатність передачі своїх знань та умінь зображувати на папері (дошці, полотні тощо) різнопланові малюнки та коментувати учням свої дії іноземною мовою; 2) володіння методичними прийомами розвитку в учнів умінь як образотворчих дій, так і дій, спрямованих на розширення їхньої англомовної комунікації; 3) можливість демонстрації досягнень своєї праці в різноманітних малюнках та їх англомовний опис.

Вважаємо, що реалізація цього принципу в процесі підготовки майбутніх учителів образотворчого мистецтва до їх англомовної діяльності призведе цей процес до його реальних практичних результатів.

Висновки. Викладений у статті матеріал дозволяє дійти таких висновків. Лінгводидак- 
тичними принципами організації підготовки майбутніх учителів початкових класів до інтегрованої професійної діяльності є такі: 1) принцип процесуальної інтеграції викладання двох різнотипних предметів у єдиному процесі навчання; 2) принцип мотивації професійної діяльності як в аспекті навчання малювання молодших школярів, так і в аспекті дослідження іноземної мови як засобу викладання основного предмета; 3 ) принцип самореалізації вчителя в його високорівневій художній майстерності та безперешкодному володінні іноземною мовою в загальнонавчальних й соціально-комунікативних формах; 4) принцип високорівневої методичної компетентності педагога, заснованої на сукупності художньо-образотворчої, лінгвокомунікативної та методичної компетенції; 5) принцип рефлексивно-зумовленої самоос- віти, який проявляється в рефлексивній потребі пізнання нової інформації, у висуванні цілей самовдосконалення та способів їх досягнення; у вивченні професійної літератури, в тому числі й іноземною мовою; у поглибленні своїх теоретичних знань шляхом різноманітної дослідницької роботи; 6) принцип безперервності освіти, який проявляється в отриманні базових знань та умінь по досліджуваним дисциплінам та їх вдосконалення протягом усього свідомого життя; 7) принцип готовності педагога до його професійної діяльності, який проявляється в здатності передачі учням своїх знань та умінь в галузі предмета, що викладається.

Викладені результати дослідження дають підстави для розробки концепції підготовки майбутніх учителів початкових класів до інтегрованої професійної діяльності.

\section{ЛIТЕРАТУРА}

1. Андрощук I. В. Теоретичні і методичні основи підготовки майбутніх учителів трудового навчання та технологій до педагогічної взаємодії у професійної діяльності : дис. ... доктора пед. наук : 13.00.04, 13.00.02. Хмельницький, 2018. 634 с.

2. Білянська М. А. Теоретичні і методичні засади підготовки майбутніх учителів біології до еколого-педагогічної діяльности у загальноосвітніх навчальних закладах : дис. ... доктора пед. наук : 13.00.04. Київ, 2018. 623 с.

3. Гончаренко С. У. Український педагогічний енциклопедичний словник. 2-ге вид., доповн. й виправл. Рівне : Волин. обереги, 2011. 519 с.

4. Демидова Т. Е. Профессиональная подготовка будущего учителя к формированию общеучебных умений у младших школьников: автореф. дис. ... доктора пед. наук: 13.00.08. Москва, 2006. 38 с.

5. Зверев И. Д. Межпредметные связи как педагогическая проблема. Советская педагогика. 1974. № 12. С. 23 -32.

6. Ищук В. В. Модель профессиональной подготовки будущих учителей физической культуры на основе контекстного и проектного обучения. Молодой учёный, 2014. № 2 (61). Ч. V. С. 765-769.

7. Клочко В. Е., Галажинський Э. В. Самореализация личности: системный взгляд. Томск : ТГУ, 1999. 154 с.

8. Мартынова Р. Ю. Психологические основы интегрированного процесса обучения образовательной и иноязычной речевой деятельности студентов неязыковых специальностей: [монография]. Одеса : Освіта України, 2016. 192 c.

9. Типова навчальна програма з навчальної дисципліни «Образотворче мистецтво (Станкове та декоративне)» елементарного підрівня початкової мистецької освіти. Укладачі: М. І. Кутняхов, М. В. Кунець, О. В. Рябічева, Ф. Ф. Чорномор. Київ. 2019. 25 с.

10. Тюников Ю. С. Методика выявления и описания интегративных процессов в учебно-воспитательной работе СПТУ. Москва : АПН СССР, 1988. 46 с.

11. Чиранова О. И. Подготовка будущего учителя к реализации эстетического потенциала начального курса математики : дис. ... канд. пед. Наук : 13.00.08. Нижний Новгород, 2006. 237 с.

12. Шквир О. Л. Теоретичні і методичні засади ступеневої підготовки майбутніх учителів початкової школи до проведення педагогічних досліджень: дис. ... доктора пед. наук: 13.00.04. Житомир. 2018. 572 с.

13. Bodnar S. The educational paradigm shift for student-centered learning in the process of globalization. Наука і освіта : науково-практичний журнал. Одеса : Південний науковий изентр НАПН Украӥни, 2016. N 10/ CXXXXXI. C. 102-109.

14. Frumkina, A. et al. Readiness of future teachers for integrated teaching of educational subjects in foreign language. Práxis Educacional. V. 16, n. 38, p. 502-514, jan. 2020. URL:http://periodicos2.uesb.br/index.php/praxis/article/ view/6023.

\section{REFERENCES}

1. Androshchuk, I. V. (2018). Teoretychni i metodychni osnovy pidhotovky maybutnikh uchyteliv trudovoho navchannya ta tekhnolohiy do pedahohichnoyi vzayemodiyi u profesiynoyi diyal'nosti [Theoretical and methodical 
foundations of training the future labour teachers to pedagogical interaction in professional activity]. Doctor's thesis. Khmelnytsky [in Ukrainian].

2. Bilyanska, M. A. (2018). Teoretychni i metodychni zasady pidhotovky maybutnikh uchyteliv biolohiyi do ekolohopedahohichnoyi diyal'nosty u zahal'noosvitnikh navchal'nykh zakladakh [Theoretical and methodical foundations of training the future biology teachers to ecological and pedagogical activity in general educational institutions]. Doctor's thesis. Kyiv [in Ukrainian].

3. Honcharenko, S. U. (2011). Ukrayinskyy pedahohichnyy entsyklopedychnyy slovnyk [Ukrainian pedagogical encyclopedic dictionary]. Rivne: Volyn. Oberehy [in Ukrainian].

4. Demidova, T. Ye. (2006). Professonalnaya podgotovka budushchego uchitelya $\mathrm{k}$ formirovaniyu obshcheuchebnykh umeniy u mladshikh shkol'nikov [Professonal training the future teachers for the formation of general educational skills in primary schoolchildren]. Extended abstract of doctor's thesis. Moscow [in Russian].

5. Zverev, Y. D. (1974). Mezhpredmetnye sviazy kak pedahohycheskaia problema [Interdisciplinary communication as a pedagogical problem]. Sovetskaia pedahohyka - Soviet Pedagogy, 12, 23-32 [in Russian].

6. Ishchuk, V. V. (2014). Model professionalnoy podgotovki budushchikh uchiteley fizicheskoy kul'tury na osnove kontekstnogo i proyektnogo obucheniya [Model of professional training the future PT teachers based on contextual and project-based teaching]. Molodoy uchenyy - Young scientist, 2 (61), part V, 765-769 [in Russian].

7. Klochko, V. E., Galazhinsky, E. V. (1999). Samorealizatsiya lichnosti: sistemnyy vzglyad [Self-realization of personality: a systemic view]. Tomsk: TSU [in Russian].

8. Martynova, R. Y. (2016). Psikhologicheskiye osnovy integrirovannogo protsessa obucheniya obrazovatel'noy $i$ inoyazychnoy rechevoy deyatel'nosti studentov neyazykovykh spetsial'nostey [Psychological foundations of the integrated process of teaching educational activity and foreign language speech activity to students of non-linguistic specialties]. Monograph. Odesa: Osvita Ukraini [in Russian].

9. Typova navchalna prohrama z navchalnoyi dystsypliny «Obrazotvorche mystetstvo (Stankove ta dekoratyvne)» elementarnoho pidrivnya pochatkovoyi mystets'koyi osvity [A typical curriculum of the discipline "Fine Arts (Easel and Decorative)" of elementary level of primary art education]. (2019). Kyiv. URL: http://arts-library.com.ua/xmlui/ handle/123456789/83 (Last accessed 30.08.2021) [in Ukrainian].

10. Tyunikov, Y. S. (1988). Metodika vyyavleniya i opisaniya integrativnykh protsessov v uchebno-vospitatel'noy rabote SPTU [Methods of identifying and describing integrative processes in teaching and in educational work of SPTU]. Moscow : APN SSSR [in Russian].

11. Chiranova, O. I. (2006). Podgotovka budushchego uchitelya k realizatsii esteticheskogo potentsiala nachal'nogo kursa matematiki [Training the future teachers for the realization of the aesthetic potential of the elementary course of mathematics]. Candidate's thesis. Nizhniy Novgorod [in Russian].

12. Shkvyr, O. L. (2018). Teoretychni i metodychni zasady stupenevoyi pidhotovky maybutnikh uchyteliv pochatkovoyi shkoly do provedennya pedahohichnykh doslidzhen [Theoretical and methodical foundations of degree preparation of future primary school teachers to conducting pedagogical researches]. Doctor's thesis. Zhytomyr [in Ukrainian].

13. Bodnar, S. V. (2016). The educational paradigm shift for student-centered learning in the process of globalization. Nauka i osvita - Science and education, 10/ CXXXXXI, 102-109 [in English].

14. Frumkina, A. et al. (2020). Readiness of future teachers for integrated teaching of educational subjects in foreign language. Práxis Educacional, 16 (38), 502-514. URL: http://periodicos2.uesb.br/index.php/praxis/article/view/6023 (Last accessed 30.08.2021) [in English].

\section{A. L. FRUMKINA}

Candidate of Philological Sciences, Associate Professor, Associate Professor at the Department of Foreign languages No. 2, National University "Odesa Law Academy", Odesa, Ukraine

E-mail:frumkina@onua.edu.ua http://orcid.org/0000-0003-2635-685X

\section{LINGUODIDACTIC PRINCIPLES OF ORGANIZING THE TRAINING OF FUTURE PRIMARY SCHOOL TEACHERS FOR INTEGRATED PROFESSIONAL ACTIVITY}

The article presents the problem of determining the principles of training the future primary school teachers for their integrated professional activity in a foreign language. The principle-forming systems of training future teachers of different 
specialties are presented and compared in the article. Linguodidactic principles of organizing the training of future primary school teachers for integrated professional activity are established. These principles are: 1) the principle of procedural integration of teaching two different subjects in a united educational process; 2 ) the principle of motivation of professional activity both in the aspect of teaching fine arts to junior students, and in the aspect of mastering a foreign language as a means of teaching the major subject in English; 3) the principle of teacher's self-realization in his high-level artistic skills and fluent mastering a foreign language in general educational and social-communicative forms; 4) the principle of teacher's high-level methodological competency, based on a set of artistic, linguo-communicative and methodological competencies; 5) the principle of reflexively conditioned self-education, which is manifested in the reflexive need to learn new information, in setting goals for self-improvement and ways to achieve them; study of the professional literature, including literature in a foreign language; attempts to realize their professional potential in new types of painting and commenting on their actions in a foreign language; deepening their theoretical knowledge through various research works; 6) the principle of continuity of education, which is manifested in the acquisition of basic knowledge and skills in the disciplines studied and their perfection throughout the whole conscious life; 7) the principle of the teacher's readiness for his professional activity, which is manifested in the ability to transfer to students his knowledge and skills in the field of the subject being taught.

Key words: linguodidactic principles, professional training, integrated learning, primary school teachers. 